Available online on 15.04.2020 at http://jddtonline.info
Open Access to Pharmaceutical and Medical Research
unrestricted non-commercial use, provided the original work is properly cited

Open@ Access

Review Article

\title{
Damshaja Shula: A Review
}

\author{
Mahadevappa Kotnalli1*, Gopendra K², Sanath Kumar T33, Gazala Hussain4 \\ $12^{\text {nd }}$ year PG Scholar, Dept. of Agada Tantra, Sri Dharmasthala Manjunatheshwara College of Ayurveda and Hospital, Hassan, India \\ ${ }^{2}$ Ayurveda Physician, Dept. of Agada Tantra, Sri Dharmasthala Manjunatheshwara College of Ayurveda and Hospital, Hassan, India \\ ${ }^{3}$ Assistant Professor, Dept. of Agada Tantra, Sri Dharmasthala Manjunatheshwara College of Ayurveda and Hospital, Hassan, India
}

${ }^{4}$ Associate Professor, Dept. of Rasashastra \& Bhaishajya Kalpana, Sri Dharmasthala Manjunatheshwara College of Ayurveda and Hospital, Hassan, India

\begin{abstract}
Ayurveda has mentioned the bite of Sarpa(snakes), Keeta(incects), Luta(spider), Vrischika(scorpion), Mooshaka(rat), etc., the Jangama Visha (animate poisons), their characteristic symptoms and its management, in a very special branch of Ayurveda termed as Agada tantra. Ayurveda Acharyas have given special attention to Jangama Visha(animate poisons) and are described in the classics as a special entity. Damsha(bite) is the most common in animal poisons. The most common and early symptom is pain. In the management of all types of jangama visha damsha traditional and regional knowledge are available. Administration of anti- venom and sthavaravisha(plant poison) are used as an antidote for all jangama visha damsha. Ayurveda has explained numerous medicinal plants in the management of jangama visha damsha. Pain management plays a major role in management of animal poisoning. Most of the Ayurveda formulations used in management of bite have multiple actions rather than on single symptom like pain.
\end{abstract}

Keywords: Pain, Sarpa, Keeta, Loota, damsha, Chikitsa

Article Info: Received 23 Jan 2020; Review Completed 22 March 2020; Accepted 29 March 2020; Available online 15 April 2020

\section{Cite this article as:}

Kotnalli M, Gopendra K, Sanath Kumar T, Hussain G, Damshaja Shula: A Review, Journal of Drug Delivery and Therapeutics. 2020; 10(2-s):171-174 http://dx.doi.org/10.22270/jddt.v10i2-s.3954

*Address for Correspondence:

Mahadevappa Kotnalli, 2nd year PG Scholar, Dept. of Agada Tantra, Sri Dharmasthala Manjunatheshwara College of Ayurveda and Hospital, Hassan, India

\section{INTRODUCTION}

Damsha (Fang or teeth bite) is the most common among jangamavishaadhishtana (animal poison base).The most common and early symptom of damsha is pain.

Pain due to damsha may be due to tissue injury causing the release of inflammatory mediators like bradykinin, serotonin, prostaglandins, cytokines, potassium, substance $\mathrm{P}$ and $\mathrm{H}+$ responsible for pain. Or, chemical contents of the poison or venom which may decrease the threshold of pain in body by contributing to increase in the amount of inflammatory mediators around the site. Ex: serotonin in scorpion venom and serotonin and kinin in wasp/hornets venom ${ }^{1}$.

Pain management plays a major role in management of animal poisoning. Most of the Ayurveda formulations used in management of bites have multiple actions rather than on single symptom like pain. 46 classical texts were reviewed and 375 formulations containing arka were found. 25 formulations were indicated for visha management, mostly as lepa (application). 22 references were found for vatavyadhi, mostly as oil and svedana (sudation). 13 formulations were found to be mentioned for wound management thatis mostly used as kwatha (decoction).

\section{Bites $^{2}$}

All the Jangamavishas(animate poisons) are responsible for damsha(bite). Mainly, the Bhoumasarpadamshtra visha, Marjara(cat), Shwana(dog), Nara(human), Manduka(frog), Keeta(incects),etc. these are the damshtra(bite)and nakhavishas(nail poisoning). Lootavisha (spider) are the lalasrava(saliavation), purisha(stool), damsha(bite), nakha(nail), shukraVishas. Makshika(honey bee), Kanabh(wasp), and Jalouka(leech) are the mukhasandamsha vishas.

\section{Snake Bites:}

Types of damshtra: According to Vagbhata ${ }^{3}$ there are five types namely Tundahata, Vyalida, Vyalipta, Damshta Nipida and Dashtaka. 
Acharya Sushruta has mentioned three types ${ }^{3}$ as Sarpita, Raditaand Nirvisha/ Sarpangabhihata

Sarpa Damsha samanya Lakshana 4

Bites of snake having poison are accompanied with swelling, pricking pain, itching and burning sensation.

\section{Cobra $^{5}$}

In cobra bite there is manifestation of Vataprakopa (aggravation of vata), krishnata (blackish discolouration), symptoms start within six to eight minutes, small reddish wheal at the site of bite, radiating and burning pain with tenderness. Pain will be in ascending order with numbness and fast spreading.

In viper bite 6 there is manifestation of Pitta prakopa, pain and oozing with burning sensation, local necrosis and gangrene, serous and serangious blisters, petechial haemorrhage, abdominal colic.

In rajimanta damsha(kraits) ${ }^{7}$ there is no swelling or burning sensation, mild pain or no pain at all. Headaches, heaviness in the body, abdominal pain, dysarthria, dysphasia, chest pain and kaphaprakopa is present.

In Sea snakes, there is very little or no local symptom and is painless.

Pain management through Ayurveda ${ }^{8}$ :

Arka Patrasvedana (except in viper bite), and irrigation of the affected part with ghee and rock salt helps in relieving the pain.

\section{In Cobra bite 9}

Mahakalyanakaghrita $15 \mathrm{ml}, 10 \mathrm{ml}$ Madhu, Bilvadi Gulikachurna is given at the earliest. Jeevaraksha Gulikawith Dugdha. After 3 rd vomiting,if symptoms persist, patient has to be referred to a higher centre.Nasya with bhringraj aswarasa mixed with Bilwadi to check paralysis, diplopia and slurring speech.Patoladiganakwatha with Bilwadiare given and repeated after $12 \mathrm{hrs}$.Trivritlehais advised to relieve constipation. ArkaPatra (Calotropis gigantea) and ishwari (Aristolachia indica) paste is smeared.

Necrotic ulcers are treated with irrigation of decoction prepared with Kaaraskaramula (strychnosnux vomica), Vata (Ficusbengalensis), Ashwatha (Ficusreligiosa), Plaksha Twak (Ficusvirens). Nasal drops prepared with Dronapushpa (Leucascephalotes), Tulasi (Ocimum tenuiflorum), Marichaas nasal drops. Exceeding 4 dropsis avoided to prevent pulmonary oedema.

\section{In viper bite ${ }^{10}$}

Patoladiganakwatha (patola, katurohini,chandana, madhusrava, guduchi, pata) with bilwadichoorna, Malatiswarasa (Aganosmaheynei) with honey relieves hemoptysis, Nimba (Azadirachta indica) leaves for hematemesis, Tarunbhaskaragulika with coconut milk to check hematuria, pippali and ela in coconut milk to check dysuriaand constipation. Shigrupunarnavadi lepa is applied to relieve oedema. Paste of the root of neeli(Indigofera tinctoria) orkaranja (Millettia pinnata) in warm water smeared over site, relieves the symptoms.

\section{In Krait bite ${ }^{11}$}

Patoladiganakwatha with bilwadigutika, root of aparajita (Clitoriaternatea) mixed with water, neeli (Indigofera tinctoria), shunti (Zingiber officinale), pippali (Piper longum)and maricha(Piper nigrum) mixed in warm water given orally. For relieving headache the paste of ishwari, vachaand hinguare made into paste and smeared over the head.

Yogas 12 - Jeevaraksha Gutika, Bilvadi Gutika, Visha bilvadi Gutika .

$>$ Jeevaraksha gutika13- vanga (tin), parada (mercury), haratala (yellow orpiment), manashila (realgar), hingula (cinnabar), tankana (borax), tuttha (blue vitriole), sphatika (alum), gandhaka (sulphur),hingu (Ferula asafoetida), saindhava (rock salt), kattuchanaka, bakulabeeja (Mimusopselengi), vacha (Acorus calamus), trikatu, ishwari (Aristolachia indica), sariva (Hemidesmusi ndicus), arka (Calotropis gigantea).

Uses - kandugna property, dahagna, shoolagna property, sothagna etc

> Bilvadi Gutika14- Bilwamoola (Aegle marmelos), tulasi puspa (Ocimum tenuiflorum), karanja fruit (Millettia pinnata), tagara (Tabernaemontana Divaricata), devadaru (Cedrus deodara), triphala, trikatu, haridra (Curcuma longa), daru haridra (Berberis aristata)

Uses- Sarpa damsha(snake bites), Loota visha (spider poison), Unduru visha (rat poison), Vrischika visha (scorpion poison), Visuchika (cholera), Ajeerna (indiges-tion), Gara visha (combination of poisons), Jwara (raise of temperature), Bhoota bhada (infectious conditions).External- application Indications for External - Sarpa, Loota, Undu-ru, Vrischika

> Visha Bilvadi Gutika15- Bilwamoola (Aegle marmelos), tulasi pushpa (Ocimum tenuiflorum), karanja fruit (Millettia pinnata), tagara (Tabernaemontana Divaricata), devadaru (Cedrusdeodara), triphala, trikatu, haridra (Curcuma longa), daru haridra (Berberis aristata), ishwari (Aristolachia indica), neelini (Indigofera tinctoria) and pata (Lawsonia inermis).

Uses - All the drugs in this yoga are krimighna and vishaghna. And their pharmacological actions revealed as antimicrobial, antiviral, anti-inflammatory, analgesic, cardio protective, antiseptic, antifungal, antidiarrheal and anti protozoal

\section{Scorpion Sting16}

Scorpions are eight legged arthropods, having two poison glands at the end part of tail. The venom contains toxalbumen having hemolytic and neurotoxic effect, Phospholipase, hyaluronidase, acetyl cholinesterase and serotonin. It causes local swelling and severe radiating pain.

\section{Management through Ayurveda:}

Dashangagulika with warm water for internal administration is mentioned. Externally, Arkapatra svedana, Dhoopana with feather of peacock and cock with saindhava (rock salt) and tilakalkais put. Lepa of karanja(Millettia pinnata) and hingu (Ferula asafoetida)help to relieve pain.

\section{For chronic case ${ }^{17}$}

Patoladigana,Parantyadigana(udumbara, ashwattha, vata, patha,paranthi, chandana, brahmi, durva, vacha, trikatu,jatamamsi, ashwagandha, etc.), Sigrupunarvadilepa (sigru, punarnava, chandana, pata, eshwari, etc.) 


\section{LootaVisha (Spider Venom) 18}

Itspoisoning may occur directly or indirectly, various parts of spider capable of causing poisoning- Shvasa, Damstra, Pureesha, Mootra, Shukra, Laala, Nakha, Arthava. Out of these bite is more poisonous. Indirectly poisoning occurs through the cloths containing poison and contact of discharge of lesion of luthavisha.

The venom contains hyaluronidase, ribonuclease, alkaline phosphatase, lipase, sphingomyelinase. Sphingomyelinase is mostly responsible for tissue destruction.

\section{Management of Spider poison 19}

Chedana, Dahakarma, Lepana, Seka-dhara (ksheervrikshatvakkwatha), Raktamokshna

For lepa- Haridra (Curcuma longa), tulasi (Ocimum sanctum), saidhava (rock salt), madhu (honey), hingu (Ferula asafoetida) and betel leaf

Formulations -Neelitulsiyadikwatha, Padmakaagada, Champakaagada, Lodhraadiagada

\section{Keeta Damsha20}

Fever(Jvara), bodyache(Angamarda), horripilation, disconforts, vomiting, thirst, burning sensation, fainting, rigors, dyspnoea, appearance colored round patches, dadru, karnika, visarpa, kitibha, these are complications produced by their bites.

\section{Centipede 21}

Parusha, Krishna, citra, kapila, pitika, rakta, shveta, agniprabha, these are the eight varieties of shatapadi, the bite of these causes swelling and pain.

\section{Wasp $^{22}$}

Visarpa, shvayathu, shula, jvara, chardi, these are symptoms are seen in wasp bite.

\section{Bee Sting23}

Makshika are mainly sixtypes, kaantaarka, Krishna, pingala, madhulika, kaashaayi, sthaalika. The bite of these causes itching, swelling, burning sensation, and pain will be present at the place of bite.When bee stings, it leaves behind the stinger and part of its abdomen. Locally there is pain, itching, redness and slight swelling at the site of sting ${ }^{23}$.

Treatment in Ayurveda includes Svedana, utkartana, raktamochhana, lepana, seka and virechana if need be. The formulation beneficial is Dashangaagada

\section{Alarka Visha Damsha ${ }^{24}$}

The premonitory stage, there is pain and discomfort at site of bite, headache, anxiety, muscular spasm, hydrophobiainvoluntary painful contractions of diaphragm, accessory respiratory, laryngeal muscles in response to swallowing fluids.

\section{Alarka Visha Chikitsa ${ }^{25}$}

Bite should be burnt by hot Ghrita and covered with warm paste of agada, Purana Ghrita should be made to drink, Kwatha of neelimoola (Indigofera tinctoria,) and karanjamoola (Millettia pinnata) administered for 14-21 days. Externally, the paste of the root and bark of ankola (Alangium salvifolium) with rice wash is applied. Wound care with triple wash, sedation for anxiety, respiratory support and hydration.

\section{Moosika Visha ${ }^{26}$}

Rat bite may cause large and triangular wound with bleeding. Pain will be trivial in rat bite. Pain may be more if the wound is large but there will not be any additional pain due to the poison. Area of wound may swell and suppurate with fever.

\section{Treatment ${ }^{27}$}

Immediately after rat bite the site should be burnt with soft of an arrow or a mirror. If not there will be either severe pain or formation of circular rings. Burnt area should be scraped and shirisha, rajani, vakra, kumkuma and amravalli paste should be applied.

\section{DISCUSSION}

Different jangamavishas have various adhisthana. However, almost all the animal may cause bites which may be poisonous or non-poisonous. Pain due to damsha may be due to tissue injury causing the release of inflammatory mediators like bradykinin, serotonin, prostaglandins, cytokines, Potassium, substance $\mathrm{P}$ and $\mathrm{H}+$ responsible for pain. Or, chemical contents of the poison/venom which may decrease the threshold of pain in body by contributing to increase in the amount of inflammatory mediators around the site.

In snake bite, larger the tissue damage, more severe is the pain. Hence, the classification of damstra as tundahat, vyalidh, vyalipta, damstanipida, damshtaka is based on the severity of tissue damage and symptoms.

Most of the chemical constituents of the snake venom play role in tissue destruction than directly causing pain. Hence more the venom injected more tissue damage and more pain.

Different types of Sarpa, Keeta, Loota, etc. have different types of dosha predominance, drugs combinations are made accordingly. Drugs which are having the vishaghna karma along with shola prashamana are used in the management of Damshajashula. Most of the drugs have madhura, katu and kashaya rasa which are generally known as shoolaghna and vishaghna.

Most of the Ayurveda formulations used in management of bites have multiple actions rather than on single symptoms like pain.46 classical texts were reviewed and 375 formulations containing arka were found.25 formulations were indicated for visha management, mostly as lepa.22 references for vatavyadhi, mostly as oil and svedana are said.13 formulations for wound management, mostly used as kwatha are mentioned.

\section{CONCLUSION}

Pain may be present in both poisonous and non-poisonous bite, however more in the earlier. Tissue damage is the main cause of local pain, venom may cause visceral and abdominal pain also. Various formulations for the management of pain are described both for local application as well as internal administration. Arka is the most commonly used drug in damshaja shola in the form of svedana, taila, kwatha. Dasangaagada can be considered as formulation of choice in damshaja shola.

\section{REFERENCES}

1. Gautam Biswas. Review of forensic medicine and Toxicology 3rd edition, New Delhi: jaypee Brothers Medical Publishers (p)Ltd.;2015

2. SushrutasamhitakalpasthanaDalhanateekaNibandhasangrahaj angamavishavijnyaniyamadhyaya chapter 3 shloka 5 page number 568-69publication;choukambha Sanskrit samsthana Varanasi Edition:2012

3. VagbhatavirachutaAstangahridyauttarasthanasarpavishaprati shedhaadhyaya chapter 36 shloka 11-13 page number 908 publication; choukhambha sanskrita samsthana Varanasi2012 
4. Sushruta samhita kalpasthana sarpavishavijnyaniyam adhyaya chapter 4 sh;oka 4 page number 571 publication: choukambha Sanskrit samsthana Varanasi Edition:2012

5. Ashtanga sangraha uttaratantrasarpavishavijnyaniya adhyaya chapter 41 shloka 43 page number 863 publication: choukhambha sanskrita samsthana Varanasi:2012

6. Sushrutasamhitakalpasthanasarpadastavishavijnyaniyakalpaa dhyayachapeter number 4 shloka 37 page number 573 publication: choukambha Sanskrit samsthana Varanasi Edition:2012

7. Ashtanga hridayauttarasthanasarpavishapratishedha adhyaya chapter 36 shloka 23 page number 909 publication: choukhambha sanskrita samsthana Varanasi:2012

8. Sushruta samhita kalpasthana sarpavisha vijnyaniyakalp adhyaya chapter 4 shloka 37 page number 573 publication: choukambha Sanskrit samsthana Varanasi Edition:2012

9. Visha Vaidhya Jyotsnika english translation chapter 4 shloka 18-19, page number35-38, published: vaidyaratnamps ayurveda college Kottkkal

10. Dr. P Unnikrishnan and Dr. George MJ, toxicology ayurvedic perspective, published by Vaidyaratnam varier ayurveda college kottekkal, first edition, 2002, page number:119-121

11. Dr. P Unnikrishnan and Dr. George MJ, toxicology ayurvedic perspective, published by Vaidyaratnam varier ayurveda college kottekkal, first edition, 2002, page number:121

12. Dr. P Unnikrishnan and Dr. George MJ, toxicology ayurvedic perspective, published by Vaidyaratnam varier ayurveda college kottekkal, first edition, 2002, page number:118

13. Kavitha K.V Et Al: A Review Article On The Pharmacological Action Of Jeevaraksha Gutika. International Ayurvedic Medical Journal \{online\} 2017 \{cited July, 2017\} http://www.iamj.in/posts/images/upload/2652_2657.pdf

14. P.U. Shubha Et Al: A Review on Bilwadi Gutika. International Ayurvedic Medical Journal \{online\} 2017 \{cited February, 2017\} Available from: http://www.iamj.in/posts/images/upload/501_506.pdf

15. Rajveer sason, Conceptual study on antitoxic effect of bilwadi gutika, WJPLS 2016

16. Dr. P Unnikrishnan and Dr. George MJ, toxicology ayurvedic perspective, published by Vaidyaratnam varier ayurveda college kottekkal, first edition, 2002, page number:162-163
17. Dr. P Unnikrishnan and Dr. George MJ, toxicology ayurvedic perspective, published by Vaidyaratnam varier ayurveda college kottekkal, first edition, 2002, page number:166

18. Ashtanga hridayauttarasthana Keetalootadichikitsitamadhyayam chapter 37 shloka 2-3 page number 914 edition:2012 publication:

choukhambhasanskritasamsthana varanasi

19. Ashtanga hridayauttarasthana Keetalootadichikitsitam adhyayam chapter 37 shloka 222-23 page number 915-916 edition:2012 publication: choukhambhasanskritasamsthana varanasi

20. Sushrutasamhitakalpasthanakeetakalp adhyaya chapter 8 shloka 19-21 page number 587 publication: choukhambha sanskrita samsthana Varanasi:2012

21. Sushruta samhita kalpasthanakeetakalp adhyaya chapter number 8 shloka 30 page number 588 publication: choukhambha sanskrita samsthana Varanasi:2012

22. Charakasamhitachikitsasthanavishachikitsaadhyayavol:2 chapter number 23 shloka number 152 page number 563 publication: choukhambha sanskrita pratisthana Varanasi:2002

23. Sushruta samhita kalpasthanakeetakalp adhyaya chapter number 8 shloka number 35 page number 588 publication: choukhambha sanskrita samsthana Varanasi:2012

24. Astanga sangraha uttaratantramushikalarkapratishedha adhyaya chapter number 46 shloka number 12 page number 893 publication: choukhambha sanskrita samsthana Varanasi:2012

25. Ashtanga hridayauttarasthana Keetalootadi chikitsita madhyayam chapter 39 shloka 2-3 page number 914 publication: choukhambhasanskritasamsthana varanasi Edition:2012

26. Astanga sangraha uttaratantramushikalarkapratishedha adhyaya chapter number 46 shloka number 35-36 page number 922 publication: choukhambhasanskritasamsthana Varanasi:2012

27. Ashtanga hriday auttarasthana Keetalootadi chikitsita madhyayam chapter 39 shloka 16-17 page number 921 publication: choukhambha Sanskrita samsthana Varanasi Edition:2012 